\title{
Growth Performance of the African Catfish, Clarias Gariepinus, Fed Varying Inclusion Levels of Talinum Triangulare as Feed Additives
}

\author{
Tiamiyu Adebisi Musefiu* \\ Department of Biological Sciences, Faculty of Science, University of Medical Sciences, Nigeria
}

Received: 制: September 18, 2018; Published: 制 October 01, 2018

*Corresponding author: Tiamiyu Adebisi Musefiu, Department of Biological Sciences, Faculty of Science, University of Medical Sciences, Laje Road, Ondo City, Nigeria

\begin{abstract}
Many medicinal plants including Talinum triangulare (Water leaf) have shown promising findings when included in aquaculture ration as feed additive. More studies are needed to investigate the potential of these medicinal plants on enhancement of growth performance in aquaculture. In this present study, a total of four diets were formulated to include T. triangulare (T.t) powder as feed additives at levels of $0.0 \%$ (T.t), $0.5 \%$ (T.t), $1.0 \%$ (T.t) and $3.0 \%$ (T.t). Fish meal (65\%) was used as a sole protein source in all the experimental diets. All the rations were isonitrogenous (35\% protein), isolipidic (11.73\% lipid) and isoenergetic ( $467.77 \mathrm{Kcal} / 100 \mathrm{~g}$ ration). Each treatment was replicated thrice and ration fed to the experimental fish at $5 \%$ body weight twice daily for 70 days. All the experimental diets had no significant effects $(P>0.05)$ on the growth of the African Catfish fingerling. The mean fingerlings final weight (g) was $1.91 \pm 0.127,2.14 \pm 0.084,2.38 \pm 0.096$ and $1.86 \pm 0.439$ for fish fed $0.0 \%$ (T.t), $0.5 \%$ (T.t), 1.0\% (T.t) and 3.0\% (T.t), respectively. The specific and relative growth rates of the fish under all the treatments were also not significant (P $>0.05$ ).

The best growth performance was observed in fish fed $1.0 \%$ (T.t) closely followed by $0.5 \%$ (T.t) ration then diet 3.0\% (T.t) and least in fish fed diet $0.0 \%$ (T.t). The survival percentage in fish fed with $0.5 \%$ (T.t) $>1.0 \%$ (T.t) $>3.0 \%$ (T.t) $>0.0 \%$ (T.t) adjudged to be good throughout the experimental period and this could be attributed to good water quality management and more so, the suitability of T. triangulare inclusion in Claria gariepinus diet. Water leaf inclusion in fish diet at $0.5-3.0 \%$ concentration is therefore beneficial for use in aquaculture to enhance growth promotion however a further research is recommended to investigate toxicity of this plant at varying inclusion levels of $0.5 \%$ to $3.0 \%$ in the Clarias gariepinus culturing to ascertain the best inclusion level.
\end{abstract}

Keywords: Catfish Fingerlings; Growth Response; Feed Additive; Talinum Triangulare

\section{Introduction}

Fish culture has become an important industry and the world's fastest growing sector of agricultural business Villa-Cruz et al. [1] FAO [2] reported that the total world fishery production decreased slightly and the human consumption for aquatic product increased over the years. The need to enhance growth performance, feed efficiency and disease resistance of cultured organisms is substantial for various sectors of this industry EL-Haroun et al. [3]. Diet supplementation is an important aspect in aquaculture management especially in intensive or in semi-intensive fish culture and is promising for increasing fish production. EL-Haroun, [4] pointed out that diet is often the single largest operating cost item that represent over $50 \%$ of the operating costs in intensive aquaculture. Traditional use of antibiotics and other chemotherapeutics in fish culture has been criticized because of the potential development of multiple antibiotic resistant bacteria, environmental pollution and the accumulation of residues in fish Ringo et al. [5]. Scientists have intensified efforts to identify and develop safe dietary supplements and additives that enhance the life activity, health and immune system of farmed fish Ji et al. [6]; Shim et al. [7].

World Health Organization encourages using of medicinal herbs and plants to substitute or minimize the use of chemicals through the global trend to go back to nature. With the shifting of attention from synthetic drugs to natural plant products, the use of plant extracts for enhancing growth performance in animals is now on the increase. Plants that were once considered of no value are now being investigated, evaluated and developed into drugs with little or no side effects. One of such plant is Talinum triangulare (Water leaf). T. triangulare is a cosmopolitan weed belonging to the Talinum genus, family Portulacaceae that grows best under humid conditions Burkill [8]. It is one of the vegetables widely cultivated and consumed in Africa especially Southern Nigeria Imoh and Julia [9]. Ezekwe et al. [10] 
reported that T. triangulare is a rich source of vitamins, $\beta$-carotene, minerals (such as calcium, potassium and magnesium), pectin, proteins and vitamins. It has also been found to possess useful medical potentials such as laxative, purgative, treatment of diarrhea, gastro-intestinal diseases Oguntona [11]; Mensor et al. [12] as well as in the management of cardiovascular diseases such as: stroke and obesity Aja et al. [13].

Previous studies on rats Ezekwe et al. [14] showed that inclusion of T. triangulare methanolic extract suggest a lot of health benefits in human and animal. However, the potential of health benefits of T. triangulare in fish has not been investigated. Clarias gariepinus (Burchell, 1822) is the most important cultivated fish in Nigeria. This species has shown considerable potential as a fish suitable for use in intensive aquaculture. In spite of the remarkable aquaculture potential of $\mathrm{C}$. gariepinus, the size obtained under culture is still poor compared to its hybrid and Heterobranchus spp Dada \& Ikuerowo [15]. There is need to enhance the culture of this valuable species for sustainable aquaculture production and also to meet the demand of the ever increasing population in the country. The objective of this study was to investigate the effects of varying dietary supplementation of T. triangulare additive on growth performance of African catfish, C. gariepinus.

\section{Materials and Methods \\ Experimental Fish}

One hundred and forty four fingerlings of Clarias gariepinus were obtained from private fish farm in Olodo, Oyo State of Nigeria. The fish were acclimatized in 50 litres plastic bowls for two weeks. During the period of acclimatization the fish were fed ad libitum Anibeze and Eze, [16] at 5\% body weight twice daily Okoye et al. [17] with a formulated diet of $35 \%$ crude protein without herbal extract and no history of herbal feeding from the farm where fish were sourced. At the end of the acclimatization period, the fish were randomly selected and assigned to four experimental groups of $0 \%$ (controls), $0.5 \%, 1.0 \%$ and $3 \%$ concentrations of $\mathrm{T}$. triangulare powder in diet at 36 fish per treatment. Twelve plastic aquaria each measuring $40 \mathrm{~cm} \times 27 \mathrm{~cm} \times 27 \mathrm{~cm}$ with each aquarium holding 12 fish were set up to maintain three replicates per treatment. Feeding was suspended 24 hours before the feeding trial to increase appetite and reception for new diet Madu \& Akilo [18].

\section{Experimental Diet}

Fishmeal, maize, wheat bran, soya bean meal, calcium carbonate and limestone sourced from local markets were used to formulate basal diets $(35 \% \mathrm{CP})$ without herbal plants. All ingredients were ground into powdery form using a mechanical grinder, and then mixed with mineral mixture and vegetable oil. The ingredients and proximate chemical composition of basal feed was estimated by the methods described by the AOAC [19]. Four different diets with or without additives, representing four dietary variants (Table 1) were then prepared by incorporated T. triangulare powder into basal diet at levels of $0.0 \%, 5.0 \%, 1.0 \%$ and $3.0 \%$. The ingredients were then thoroughly mixed together by hand. Warm water was added to the premixed ingredients and homogenized to a dough- like paste. The diets were then pelletised using $0.5 \mathrm{~mm}$ pellet press. The diets were sun-dried for 4 days and labeled appropriately and stored in airtight containers throughout the experimental period.

Table 1: Composition of experimental diet.

\begin{tabular}{|c|c|c|c|c|}
\hline \multirow{2}{*}{ Ingredients } & \multicolumn{5}{|c|}{ Concentration of Talinum triangulare in } \\
diet \\
\hline & $\mathbf{0 \%}$ & $\mathbf{0 . 5 \%}$ & $\mathbf{1 . 0 \%}$ & $\mathbf{3 . 0 \%}$ \\
\hline Yellow corn (g) & 35.0 & 35.0 & 35.0 & 35.0 \\
\hline Soybean meal (44\%)(g) & 28.5 & 28.5 & 28.5 & 28.5 \\
\hline Fish meal (65\%)(g) & 17.0 & 17.0 & 17.0 & 17.0 \\
\hline Wheat bran(g) & 9.5 & 9.5 & 9.5 & 9.5 \\
\hline T.t Powder(g) & 0.0 & 0.5 & 1.0 & 3.0 \\
\hline Calcium Carbonate(g) & 0.3 & 0.3 & 0.3 & 0.3 \\
\hline Ground lime stone(g) & 0.7 & 0.7 & 0.7 & 0.7 \\
\hline Vegetable Oil(ml) & 6.5 & 6.5 & 6.5 & 6.5 \\
\hline Mineral mixture (g) & 1.7 & 1.7 & 1.7 & 1.7 \\
\hline Vitamin mixture(g) & 1.0 & 1.0 & 1.0 & 1.0 \\
\hline
\end{tabular}

\section{Experimental Procedure}

Feeding of Fish: Fish in all the treatments were fed two times a day (morning 9 am and evening $4 \mathrm{pm}$ ) at the rate of $5 \%$ body weight per day. Feeding allowance was adjusted in accordance with increase in body weight (Hogendoorn \& koops, 1983) and diet allotments were increased weekly after the length-weight determination. The feeding last for a period of 70 days. Feed not consumed and faecal matter were siphoned out every day. Dead fish were picked daily and recorded.

Monitoring of Water Quality: Water quality parameters were managed and maintained as recommended by Boyd and Lickotcoper [20]. Water quality parameters were taken weekly throughout period of the experiment. Water temperature (o C), Dissolved Oxygen (DO), pH, Total Dissolved solids (TDS), Ammonia (NH3) and Nitrite (NO2) were measured using a portable HannaR H198186 meter and Aqua chek® (USA) water quality test stripes. The water in the tanks was drained and replaced every day.

Data Collection: Fish in each tank were batch weighed at the commencement of the study and weekly thereafter with digital electronic weighing balance to the nearest gram. The ration was adjusted every week when new mean weights of fish for the various experimental units were determined. The standard length was determined with a graduated tape. Data on performance such as body weight changes, relative weight gain, specific growth rate, feed conversion ratio, condition factors Bagenal, [21] and survival percentage Fasakin et al., [22] were determined using the following formulae: fish

a) Weight gain $(\mathrm{g})=$ Final weight of fish - Initial weight of

b) Relative weight gain $(\mathrm{RWG}, \%)=\frac{\text { Weightgain }}{\text { InitialWeight }} \mathrm{X} 100$

c) Specific growth rate (SGR) was calculated as: 
a. $\quad \operatorname{SGR}(\%$ per day $)=\frac{\left(n e t \log W_{2}-n e t \log W_{1}\right)}{T_{2}-T_{1}} \times 100$

Where:

$$
\begin{aligned}
& \mathrm{W}_{2}=\text { Weight of fish at time } \mathrm{T} 2 \text { (final) } \\
& \mathrm{W}_{1}=\text { Weight of fish at time T1 (initial) }
\end{aligned}
$$

i. Feed conversion ratio (FCR).

This was calculated from the relationship of feed intake and wet weight gain

$$
\text { FCR }=\frac{\text { Totalfeedconsumedbyfish }(g)}{\text { Weightgainbyfish }(g)}
$$

ii. Mortality (M) was calculated as:

$$
\mathrm{M}(\%) \quad=\frac{\left(N_{o}-N_{t}\right)}{N_{o}} \times 100
$$

a. Where:

$\mathrm{N}_{\mathrm{o}}=$ Number of fish at the start of the experiment

$\mathrm{N}_{\mathrm{t}}=$ Number of fish at the end of the experiment

iii. Condition factor $(\mathrm{K})$ was calculated as:

$$
K=\frac{W}{L^{3}} X 100
$$

Where:

$$
\begin{aligned}
& \mathrm{W}=\text { Weight of fish }(\mathrm{g}) \\
& \mathrm{L}=\text { Standard length of fish }(\mathrm{cm})
\end{aligned}
$$

\section{Data Analysis}

All data were subjected to analysis of variance (ANOVA) using Graph Pad Prism Software Version 5.1 Mean values of the water quality parameters and mean values of weight measurements were calculated. The results were presented as mean \pm SE (standard error). All measurements were subjected to Analysis of variance (ANOVA) and Tukey Test was used to rank the means. All differences were regarded as significantly different at $\mathrm{P}<0.05$ among treatment groups.

\section{Results}

\section{Water Quality Measurements}

The water quality parameters monitored in plastic aquaria tanks under laboratory conditions, as indicated in Table 2 were fairly stable in all the treatments. Water quality parameters were not significantly different $(\mathrm{P}>0.05)$ between treatments and were within the recommended ranges for the culture of $\mathrm{C}$ Gariepinus Viveen et al. [23].

Table 2: Water quality fluctuations in experimental tanks containing the African catfish, Clarias gariepinus.

\begin{tabular}{|c|c|c|c|c|}
\hline Treatment & $\mathbf{0 . 0 \%}$ & $\mathbf{0 . 5 \%}$ & $\mathbf{1 . 0 \%}$ & $\mathbf{3 . 0 \%}$ \\
\hline Parameters & & & & $28.00 \pm 0.30 \mathrm{a}$ \\
\hline Temp(0C) & $28.03 \pm 0.28 \mathrm{a}$ & $28.00 \pm 0.30 \mathrm{a}$ & $6.97 \pm 0.33 \mathrm{a}$ & $6.45 \pm 0.02 \mathrm{a}$ \\
\hline DO $(\mathrm{mg} / \mathrm{l})$ & $6.42 \pm 0.06 \mathrm{a}$ & $6.51 \pm 0.04 \mathrm{a}$ & $7.10 \pm 0.0 \mathrm{a}$ & $7.07 \pm 0.03 \mathrm{a}$ \\
\hline $\mathrm{pH}$ & $7.10 \pm 0.0 \mathrm{a}$ & $7.10 \pm 0.0 \mathrm{a}$ & $0.0 \pm 0.0 \mathrm{a}$ & $0.0 \pm 0.0 \mathrm{a}$ \\
\hline NH3 $(\mathrm{mg} / \mathrm{l})$ & $0.0 \pm 0.0 \mathrm{a}$ & $0.0 \pm 0.0 \mathrm{a}$ & $0.01 \pm 01 \mathrm{a}$ & $0.02 \pm 0.01 \mathrm{a}$ \\
\hline NO2 $(\mathrm{mg} / \mathrm{l})$ & $0.01 \pm 0.01 \mathrm{a}$ & $0.01 \pm 01 \mathrm{a}$ & $72.67 \pm 0.67 \mathrm{a}$ & $76.33 \pm 1.45 \mathrm{a}$ \\
\hline TDS $(\mathrm{ppm})$ & $70.67 \pm 5.46 \mathrm{a}$ & $75.67 \pm 1.20 \mathrm{a}$ & & \\
\hline
\end{tabular}

Note: Average of 10 weeks readings. Mean values with the same superscript letter in the same row are not significantly different $(\mathrm{p}>0.05)$. Control $(0.0 \%)$.

\section{Growth Performance}

Growth performance of the Clarias gariepinus fingerlings fed locally made feed containing varying quantities of T. triangulare powder as feed additives over a 70 days period is presented in Table 3. Average of initial body weight of C. gariepinus fed the experimental diets at the start did not differ, indicating that groups were homogenous. Fish were able to utilize the test diets at varying degrees but average weight gain (AWG), Feed Conversion Ratio (FCR), Specific Growth Rate (SGR), Mortality (M), Condition Factor (K) of fish were only marginally different $(\mathrm{P}>0.05)$. However, the mean final body weight $(\mathrm{MFBW})$, was significantly $(\mathrm{P}<0.05)$ higher than the initial fish weight in all diet treatment groups (Table 3 ). The best growth performance, Feed Conversion Ratio and Condition Factor were observed in the group of fish fed $1.0 \%$ T. triangulare. However, highest survival rate (SR) of $83.34 \pm 8.33 \%$ was observed in the group of fish fed $0.5 \% \mathrm{~T}$. triangulare while lowest SR of $75.00 \pm 4.81 \%$ were observed in both control group and in the group of fish fed $3.0 \% \mathrm{~T}$. triangulare.

Table 3: Growth performance of Clarias gariepinus fingerlings fed different concentration of Talinum triangulare as feed additives.

\begin{tabular}{|c|c|c|c|c|}
\hline & $\mathbf{0 . 0 \%}$ & $\mathbf{0 . 5 \%}$ & $\mathbf{1 . 0 \%}$ & $\mathbf{3 . 0 \%}$ \\
\hline Parameters & & & & $1.10 \pm 0.015^{\mathrm{a}}$ \\
\hline $\mathrm{MIBW}^{1}(\mathrm{~g})$, & $1.07 \pm 0.240^{\mathrm{a}}$ & $1.05 \pm 0.029^{\mathrm{a}}$ & $2.38 \pm 0.096^{\mathrm{b}}$ & $1.09 \pm 0.049^{\mathrm{a}}$ \\
\hline $\mathrm{MFBW}^{2}(\mathrm{~g})$ & $1.91 \pm 0.127^{\mathrm{b}}$ & $2.14 \pm 0.084^{\mathrm{b}}$ & $1.86 \pm 0.439^{\mathrm{b}}$ \\
\hline $\mathrm{AWG}^{3}(\mathrm{~g})$ & $0.84 \pm 0.107^{\mathrm{a}}$ & $1.09 \pm 0.113^{\mathrm{a}}$ & $1.085^{\mathrm{a}}$ & $0.87 \pm 0.110^{\mathrm{a}}$ \\
\hline $\mathrm{RWG}^{\mathrm{a}}(\%)$ & $78.9 \pm 8.87 \mathrm{a}$ & $104.9 \pm 13.63 \mathrm{a}$ & $116.3 \pm 6.82 \mathrm{a}$ & $97.9 \pm 5.69 \mathrm{a}$ \\
\hline
\end{tabular}




\begin{tabular}{|c|c|c|c|c|}
\hline SGR5 & $0.36 \pm 0.029 \mathrm{a}$ & $0.44 \pm 0.043 \mathrm{a}$ & $0.48 \pm 0.019 \mathrm{a}$ & $0.42 \pm 0.017 \mathrm{a}$ \\
\hline FCR6 (gg-1) & $5.77 \pm 0.53 \mathrm{a}$ & $5.14 \pm 0.45 \mathrm{a}$ & $4.65 \pm 0.11 \mathrm{a}$ & $5.45 \pm 0.69 \mathrm{a}$ \\
\hline SR7 (\%) & $75.00 \pm 4.81 \mathrm{a}$ & $83.34 \pm 8.33 \mathrm{a}$ & $80.56 \pm 7.35 \mathrm{a}$ & $75.00 \pm 4.78 \mathrm{a}$ \\
\hline CF8 (K) & $0.80 \pm 0.03 \mathrm{a}$ & $0.87 \pm 0.06 \mathrm{a}$ & $0.94 \pm 0.02 \mathrm{a}$ & $0.86 \pm 0.10 \mathrm{a}$ \\
\hline
\end{tabular}

Note: Data are represented as mean of three samples replicates \pm standard error. Mean values with the same superscript letter in the same row are not significantly different ( $\mathrm{p}>0.05) .{ }^{1}$ Mean Initial body weight, ${ }^{2}$ Mean Final Body Weight, ${ }^{3}$ Average Weight Gain, ${ }^{4}$ Relative Weight Gain, ${ }^{5}$ Specific Growth Rate, ${ }^{6}$ Feed Conversion Rate, ${ }^{7}$ Survival Rate, ${ }^{8}$ Condition Factor.

\section{Discussion}

The need to understand the roles of phyto-additives in aquaculture has led to various investigation of different herbal plants in aquaculture feed. To date a variety of herbs and spices have been successfully used in fish culture as growth promoters and immune stimulants Irkin et al. [24]. When medicinal plants are used in fish diets, one of the common problems encountered is the acceptability of the feed by fish, and this frequently relates to the palatability of the diet Rodriguez et al. [25]. In this present investigation, the experimental diet variants were accepted by Clarias gariepinus fingerlings, indicating that the levels of incorporation of herbal plant used did not affect the palatability of the diets. This might be attributed to the processing technique which involved air drying techniques that might have reduced the anti-nutrient factors that may be present in this plant thereby not affecting the palatability of the diets. This observation corroborates the works of Fagbenro [26], Francis et al. [27] and Siddhuraju \& Becker [28]. These workers reported that reduction in anti-nutrient by different processing like soaking, and drying techniques resulted in better palatability and growth in fish. Medicinal plants have received increasing attention as spices for human and additives in diets for animals.

However, only few studies have been done on the use of feed additives in fish nutrition Lawhavinit et al. [29] and more so medicinal plants as feed additives in rearing of African catfish in this part of the world. The results in this experiment suggest that dietary feed additive of Talinum triangulare had no effect on growth of Clarias gariepinus fingerlings as evidenced by similar body weight gain among treatment groups fed supplemented diet. However, all treated groups showed improved weight gain, Feed Conversion Ratio and Condition Factor and higher survival rate (SR) compared to group of fish fed diet that did not supplemented (Control diet) and best results were observed in the group of fish fed $10 \mathrm{~g} / \mathrm{kg}$ of Talinum triangulare. More so, final fish weights were higher than the initial weights in all the groups, this indicates no negative growth as a result of diet supplementation. Ndong and Fall [30] reported that garlic supplemented diet resulted in decreased body weight gain in juvenile hybrid tilapia (Oreochromis niloticus x Oreochromis aureus) fed diets supplemented with $0.5 \mathrm{~g} / \mathrm{kg}$ garlic over 4 weeks. The slow weight gains recorded in this experiment might be attributed also to the fact that fish were fed exclusively on the formulated feeds without having access to natural feed as may be found in pond or riverine conditions. The African catfish is omnivorous and feeds from a wide array of organisms under natural conditions.

\section{Conclusion and Recommendation}

This study has shown that $0.5-3.0 \%$ waterleaf supplement in fish feeds enhance growth of $\mathrm{C}$. gariepinus, however the inclusion rate at $1.0 \%$ proved to be more beneficial than other inclusion rates used in the experiment. Further research is recommended to investigate toxicity of this plant at varying inclusion levels of $0.5 \%$ to $3.0 \%$ in the Clarias gariepinus culturing to prove the safety of this plant [31]. It is also recommended that good aquaculture practice which include good quality water management among others be ensured in aquaculture practice.

\section{Acknowledgment}

The authors wish to acknowledge various sources of references for this work. More so, the management and staff of F. M Sanusi Aqualife Farms, Olodo Ibadan, Oyo State, Nigeria were appreciated for supplying fish used in this study and for their technical advice and encouragement.

\section{References}

1. Villa Cruz V, Davila J, Viana MT, Vazquez Duhalt R (2009) Effect of broccoli (Brassica oleracea) and its phytochemical sulforaphane in balanced diets on the detoxification enzymes levels of tilapia (Oreochromis niloticus) exposed to a carcinogenic and mutagenic pollutant. Chemosphere 74: 1145-1151.

2. FAO (2010) The State of World Fisheries and Aquaculture. p. 197.

3. EL Haroun ER, Ma A, Goda S, Kabir Chowdhury MA (2006) Effect of dietary probiotic Biogens supplementation as growth promoter on growth performance and feed utilization of Nile tilapia, Oreochromis niloticus (L.). Aquac Res 37: 1473-1480.

4. EL Haroun ER (2007) Improved growth rate and feed utilization in farmed African catfish Clarias gariepinus (Burchell 1822) thought a growth promoter Biogen $®$ supplementation. Jour Fish Aqult Scien 2: 319-327

5. Ringo E, Olsen RE, Gifstad TO, Dalmo RA, Amlund H, et al. (2010) Prebiotics in aquaculture: a review. Aquaculture Nutrition 16: 117-136.

6. Ji SC, Takaoka O, Jeong GS, Lee SW, Ishimaru K, et al. (2007) Dietary medicinal herbs improve growth and some non-specific immunity of red sea bream Pagrus major. Fisheries Science 73: 63-69

7. Shim SM, Ferruzzi MG, Kim YC, Janle EM, Santerre CR (2009) Impact of Phytochemical-rich foods on bioaccessibility of mercury from fish. Food Chemistry 112: 46-50.

8. Burkill HM (1994) The Useful Plants of West Tropical Africa. Volume 2: Families EI. Kew. Royal Botanic Gardens, Kew.

9. Imoh EU, Julia OM (2000) Nutrient requirement for the growth of water leaf (Talinum triangulare) in Uyo Metropolis, Nigeria. The Environ 21: 153-159.

10. Ezekwe MO, Besong SA, Igbokwe PE (2001) Beneficial influence of purslane and waterleaf supplement to Humans. FASEB J 16(4): A639.

11. Oguntona T (1998) Green Leafy Vegetables. In: Nutritional Quality of Plant Food, Osagie, AU, Eka OU (Eds.) Ambik Press pp. 120-133.

12. Mensor LL, Fabio SM, Gildor GL, Alexander SR, Tereza CD, et al. (2001) Screening of Brazilian plant extracts for antioxidant activity by the use of DPPH free radical methods. Phytother Res 15(2): 127-130. 
13. Aja PM, Okaka ANC, Onu PN, Ibiam U, Urako AJ (2010) Phytochemica composition of Talinum triangulare (Water Leaf) Leaves. Pak J Nutr 9: 527-530.

14. Ezekwe CI, Uzomba Chidinma R, Ugwu Okechukwu PC (2013) The Effect of Methanol Extract of Talinum Triangulare (Water Leaf) on the Hematology and Some Liver Parameters of Experimental Rats. Global Journal of Biotechnology \& Biochemistry 8 (2): 51-60.

15. Dada AA, Ikuerowo M (2009) Effects of ethanolic extracts of Garcinia kola seeds on growth and haematology of catfish (Clarias gariepinus) broodstock. African Journal of Agricultural Research 4(4): 344-347.

16. Anibeze CIP, Eze A (2000) Growth response of two African Catfishes (Osteichthys: Clariidae) in Homestead concrete ponds. Journal of Aquatic Sciences 15: 55-58.

17. Okoye FC, Eyo AA, Aminu NG (2001) Growth of Tilapia Oreochromis niloticus hybrid fingerlings fed lipid-based diets. In: Fish Nutrition and Fish Feed Technology, Eyo AA (Eds.). Proceedings of the First National Symposium of Fish Nutrition and Fish Feed Technology held at NIOMAR Lagos p. 52-57.

18. Madu CT, Akilo KT (2001) The use of live maggot and live tilapia fry as unconventional diets for Juveniles of the catfish Clarias anguillaris L. In: Fish Nutrition and Fish Feed Technology Eyo AA (Eds.). Proceedings of the First National Symposium of Fish Nutrition and Fish Feed Technology held at NIOMAR Lagos p. 75-83.

19. Gaithersburg MD (2005) AOAC International Official Methods of Analysis. AOAC International.

20. Boyd CE and Lickotkoper F (1990) Water quality in pond for aquaculture Alabama Agric. Experimental Station Auburn University, Alabama p. 30.

21. Bagenal TB (1978) Methods of assessment of fish production in fresh water. Blackwell Science publication OxfordIBP. Handbook No. 3, p. 35

22. Fasakin EA, Falayi AA, Eyo AA (2000) Inclusion of Poultry manure in the diet for Nile Tilapia (O. niloticus) L. Journal of Fish Tech 2: 51-56.

\section{ISSN: 2574-1241}

DOI: 10.26717/BJSTR.2018.09.001812

Tiamiyu Adebisi Musefiu. Biomed J Sci \& Tech Res

This work is licensed under Creative

Commons Attribution 4.0 License

Submission Link: https://biomedres.us/submit-manuscript.php
23. Viveen WJ AR, Richter CJJ, Van Oordt PG, Janssen JAL, Huisman EA (1986) Practical manual for the African Catfish, Clarias gariepinus. Section for Research and Technology, Box 20061, 2500EB. The Haque, Netherlands p. 121.

24. Irkin LC, Yigit M, Yilmaz S, Maita M (2014) Toxicological Evaluation of DietaryGarlic (Allium sativum) Powder in European Sea Bass Dicentrarchus labrax Juveniles. Food and Nutrition Sciences 5: 989-996.

25. Rodriguez SM, Olvera NMA, Carmona OC (1996) Nutritional value of animal by product meal in practical diets for Nile Tilapia, Oreochromis niloticus (L) fry. Aquaculture Res 27: 67-73.

26. Fagbenro OA (1999) Comparative evaluation of heatprocessed winged bean (Psophocarpus tetragonolobus) meals as partial replacement for fishmeal in diets for African catfish (Clarias gariepinus). Aquaculture 170: 297-305.

27. Francis G, Makkar HPS, Becker K (2001) Antinutritional factors present in plant-derived alternate fish feed ingredients and their effects in fish. Aquaculture 199: 197-227

28. Siddhuraju P, Becker K (2003) Comparative nutritional evaluation of differentially processed mucuna seeds (Mucuna pruriens (L.) DC var. utilis (Wall ex Wight) Baker ex Burck, on growth performance, feed utilization and body composition in Nile Tilapia (Oreochromis niloticus L.) Aquaculture 34: 487-500.

29. Lawhavinit O, Sincharoenpokai P, Sunthornandh P (2011) Effects of ethanol turmeric (Curcuma longa Linn.) extract against shrimp pathogenic Vibrio spp. and on growth performance and immune status of white shrimp (Litopenaeus vannamei). Kasetsart Journal of Nat Sci 45: 70-77.

30. Ndong D, Fall J (2007) The effect of garlic (Allium sativum) on growth and immune responses of hybrid tilapia (Oreochromis niloticus $\mathrm{x}$ Oreochromis aureus) ASFA/Fisheries biology 5: 3-11.

31. Hogendoorn H, Vismans MM (1980) Controlled propagation of the African Catfish Clarias lazera $(\mathrm{C} \& \mathrm{~V}) .11$ Artificial reproductions: Aquaculture 21: 39-53.

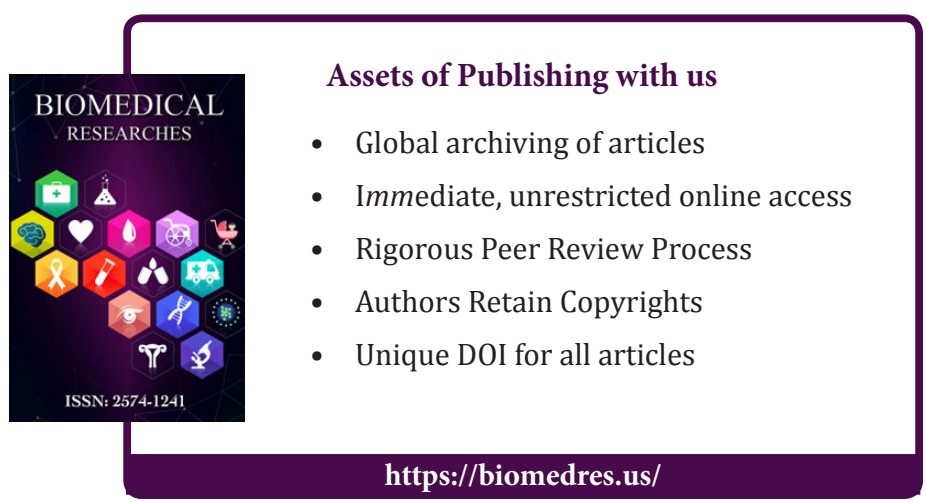

